
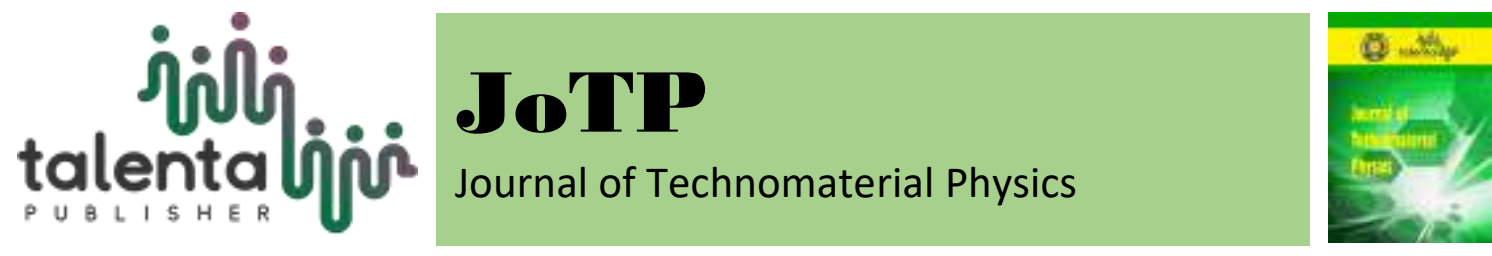

\title{
Characterization of the Volcanic Rocks of Mount Sinabung, Simacem Village, Karo Regency, Conducted With XRD, SEM-EDX
}

\author{
Perdinan Sinuhaji ${ }^{1}$, Awan Maghfirah ${ }^{2}$ and Sahat M. Nababan ${ }^{3}$ \\ 1,2,3 Department of Physics, Faculty of Mathematics and Natural Science, Universitas Sumatera Utara \\ 20155, Indonesia
}

\begin{abstract}
The study of volcanic rocks characterization of Sinabung Volcano erupted on September 15, 2017. The volcanic rocks crystal system was performed with XRD, elemental analysis and microstructure with SEM-EDX. Volcanic rocks contain: Anorthite phase 87,11 (wt\%), Triclinic crystal, lattice constant, $\mathrm{a}=8.1742 \AA, \mathrm{b}=12.844 \AA \mathrm{A}, \mathrm{c}=$

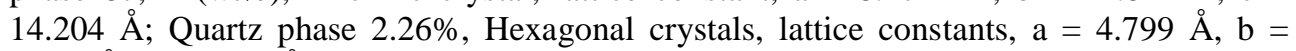
$4.799 \AA, c=5.379 \AA$; Cristobalite phase 7.72 (wt\%), Tetragonal crystals, lattice constants a $=4.970 \AA, \mathrm{b}=6.990 \AA, \mathrm{c}=6.998 \AA$; Alunite phase 2.91 (wt\%), Hexagonal crystals, lattice constants, $\mathrm{a}=6.990 \AA, \mathrm{b}=6.990 \AA, \mathrm{c}=17.282 \AA$.
\end{abstract}

Keyword: Volcanic rock, Crystal Structure, Phase, Microstructure

Received 1 December 2018 | Revised [3 January 2019] | Accepted [28 February 2019]

\section{Introduction}

Mount Sinabung's activity aroused after its 400 -year slumber. The activity was firstly noticed on August 27th, 2010. Hot clouds, lava, volcanic dust, sand and volcanic rocks were seen bursting out from the bowels of the mountain. Volcanic dust was bursting high and far, reaching tens of kilometers along with sand and volcanic rocks to residential areas. The adverse impacts inflicted to the residents were including the agricultural damage, water pollution, health problems and flight disruption [1]. The volcanic dust of Mount Sinabung contains some elements such as Nitrogen $(\mathrm{N})$ 0.13\%, Potassium $\left(\mathrm{K}_{2} \mathrm{O}\right)$ 0.55\%, Carbon (C-Organic) 0.54\%, Phosphor $\left(\mathrm{P}_{2} \mathrm{O}_{5}\right)$ 0.55\%, Silica $\left(\mathrm{SiO}_{2}\right) 59.92 \%$, Sulfur (S) 0.18\%, Iron (Fe) 16.11\% [1]. Albert Daniel [2] in his research stated that volcanic dust contains silicon dioxide $\left(\mathrm{SiO}_{2}\right)$ dominated by hexagonal structure. The volcanic dust of Mount Sinabung has the structure of a crystal which microscopically looks pointy and irregular in shape [1] [2]. This makes the volcanic dust of Mount Sinabung hazardous to people who reside at the surroundings, especially to their health, as the dust might cause bronchitis and eye irritation [3-7].

\footnotetext{
*Corresponding author at: Jl. Bioteknologi No.1 Kampus USU, Medan, Indonesia, 20155

E-mail address: perdinan@usu.ac.id
} 
In this matter, the researcher would like to study the characteristics of the volcanic rocks and volcanic dust, especially those which are harmful to human health. On the other hand, the researcher would also like to know the beneficiary use of volcanic dust, black and red volcanic rocks $[8,9]$. The volcanic rocks were collected from Simacem Village in Karo Regency, which is located 2 kilometers from the volcano and crystal analysis system with XRD [10-14] and microstructure analysis with SEM-EDX [15-20].

\section{Materials and Methods}

The sample used in this research were the volcanic rocks, collected from Simacem Village, Namanteran Sub-District, Karo Regency, North Sumatera, located 2 kilometers from the center of eruption. The rocks were broken into pieces, grinded in ball mill, and sifted to 100 mesh in size, and then dried. $50 \mathrm{~g}$ of volcanic rocks powder were used as the sample of crystal analysis system, phase analysis by XRD, and the other $50 \mathrm{~g}$ powder were used for elemental and microstructure analysis with SEM-EDX.

\section{Result and Discussion}

\subsection{The Structure Analysis of Volcanic Rocks}

Following is the obtained diffraction pattern of volcanic rocks as seen in Figure 1:

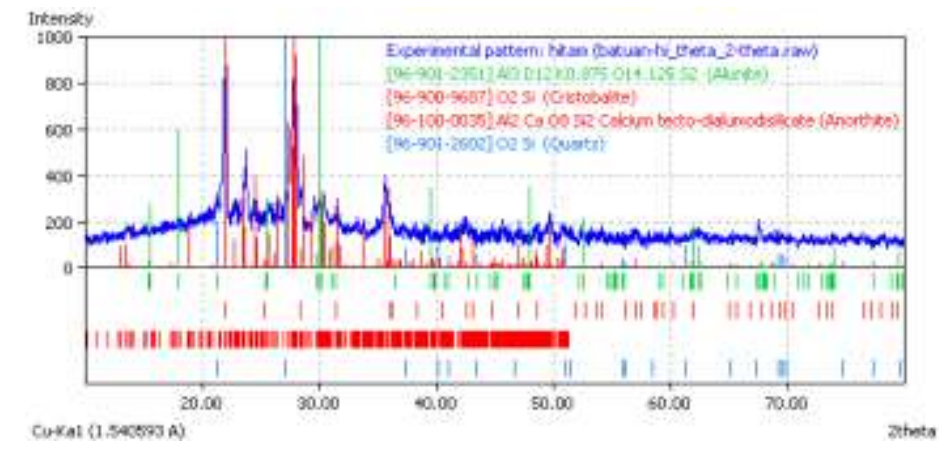

Figure 1. The Diffraction Pattern of Volcanic Rocks from Mount Sinabung

The figure above indicates that the edges of volcanic rocks contain the Anorthite phase, $\mathrm{Al}_{2} \mathrm{CaO}_{8} \mathrm{Si}_{2}$; Quartz, $\mathrm{SiO}_{2}$; Cristobalite, $\mathrm{SiO}_{2}$; Alunite, $\mathrm{Al}_{3} \mathrm{H}_{12} \mathrm{~K}_{0.875} \mathrm{O}_{14.125} \mathrm{~S}_{2}$. The Anorthite compounds contain the Triclinic crystal system, with lattice constant a $=8.174(2) \AA$, $\mathrm{b}=12.844(3) \AA, c=14.204(3) \AA, \alpha=93.4(2)^{\circ} \beta=116.1(2)^{\circ} \gamma=90.3(2)^{\circ}$, The density of Anorthite reaches $=2.768{\mathrm{~g} . \mathrm{cm}^{-3}}^{-3}$ Quartz compounds contain the Hexagonal crystal system, with lattice constant of $a=4.799(1) \AA, b=4.799(1) \AA, c=5.397(1) \AA, \alpha=\beta=90^{\circ}$ and $\gamma=120^{\circ}$, The density of

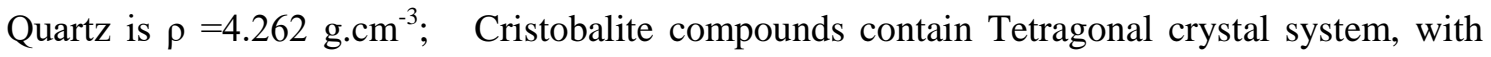
lattice constant $\mathrm{a}=4.970(3) \AA, \mathrm{b}=4.970(3) \AA$ and $\mathrm{c}=6.998(8) \AA, \alpha=\beta=\gamma=90^{\circ}$. The density is $\rho$ $=2.308 \mathrm{~g} \cdot \mathrm{cm}^{-3}$; While Alunite compounds contain Hexagonal crystal system, with lattice constant a: 6.990(9) $\AA, \mathrm{b}=6.990(9) \AA$, and $\mathrm{c}=17.282(2) \AA, \alpha=\beta=90^{\circ}$ and $\gamma=120^{\circ}$, with 
density $\rho=2.843 \mathrm{~g} . \mathrm{cm}^{-3}$. The volcanic rocks contain Anorthite phase of 87.11 (wt\%), Quartz phase of 2.26 (wt \%), Cristobalite phase of $7.72(\mathrm{wt} \%)$ and Alunite phase of 2.91 (wt\%). [8] [10]. This volcanic rocks microstructure analysis was conducted with SEM-EDX, as shown in Figure 2 below:

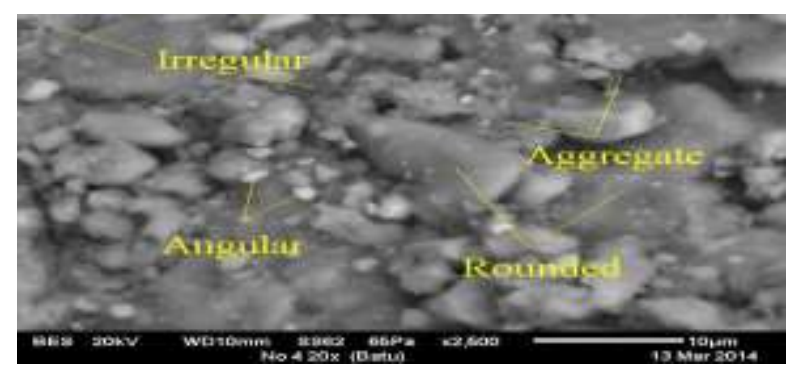

Figure 2. The Microstructure of Volcanic Rocks

The general topography of volcanic rocks is round with varied sizes, while some rocks are oval with some fine aggregate. The elemental spectrum analysis of the volcanic rocks from Mount Sinabung is presented in Figure 3:

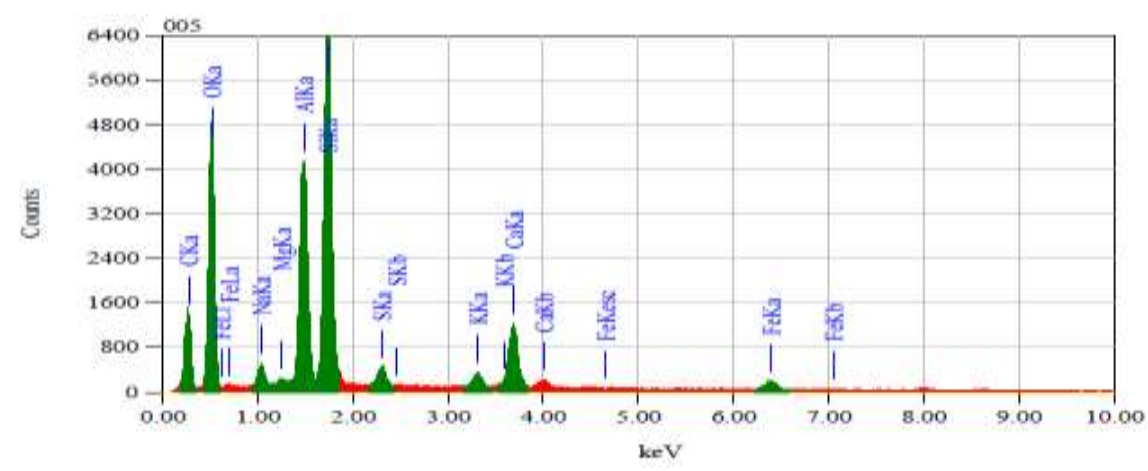

Figure 3. The Elemental Spectrum Analysis of The Volcanic Rocks of Mount Sinabung

The elemental analysis of volcanic rocks can be done with the help of computer, as identified in this following table:

Table 1. The Elemental Analysis of Volcanic Rocks

\begin{tabular}{|c|c|c|c|c|c|c|c|c|}
\hline \multicolumn{9}{|c|}{$\begin{array}{l}\text { zar Method Standardless Quantitative dsalysis } \\
\text { Fitting Coefficient : } 0.2428\end{array}$} \\
\hline $\begin{array}{l}\text { Elenent } \\
\text { C } \mathbf{R}\end{array}$ & $\begin{array}{l}\text { (keV) } \\
0.277\end{array}$ & $\begin{array}{l}\text { Mass4 } \\
23.22\end{array}$ & $\begin{array}{r}\text { Errort } \\
0.14\end{array}$ & $\begin{array}{l}\text { Atcost } \\
39.10\end{array}$ & Compound & Hass? & Cation & 6.8946 \\
\hline o $\mathrm{x}$ & 0.525 & 45.64 & 0.22 & 48.84 & & & & 49.6220 \\
\hline $\operatorname{Ban} \mathrm{X}$ & 1.041 & 1.26 & 0.13 & 0.94 & & & & 1.4692 \\
\hline $\mathrm{Hg} \mathrm{R}$ & 1.253 & 0.30 & 0.10 & 0.21 & & & & 0.3105 \\
\hline al $\mathrm{K}$ & 1.486 & 8.44 & 0.09 & 5.36 & & & & 10.5487 \\
\hline $51 \mathrm{~K}$ & 1.739 & 14.32 & 0.10 & 8.73 & & & & 19.0862 \\
\hline $3 x$ & 2.307 & 0.85 & 0.08 & 0.45 & & & & 1.3838 \\
\hline $\mathrm{K} \mathbf{R}$ & 3.312 & 0.78 & 0.12 & 0.34 & & & & 1.3878 \\
\hline $\mathrm{Ca} K$ & 3.690 & 3.71 & 0.13 & 1.59 & & & & 6.9635 \\
\hline $\mathrm{Fe} \mathbf{R}$ & 6.398 & 1.48 & 0.30 & 0.45 & & & & 2.3335 \\
\hline Total & & 100.00 & & 100.00 & & & & \\
\hline
\end{tabular}

\subsection{The Composition Analysis of The Volcanic Rocks of Mount Sinabung}

The mass fraction of volcanic rocks was analyzed from the highest peak of elemental spectrum analysis with the help of computer program. The percentage data are presented in table 2 : 
Table 2. The Mass Fraction of the Volcanic Rocks of Mount Sinabung

\begin{tabular}{lllcc}
\hline No & \multicolumn{1}{c}{ Compounds } & \multicolumn{1}{c}{ Phase } & \multicolumn{1}{c}{ Reference } & Mass Fraction \\
\hline 1. & Anorthite & $\mathrm{Al}_{2} \mathrm{CaO}_{8} \mathrm{Si}_{2}$ & ICDD- 96-100-0035 & 87.11 \\
2. & Quartz & $\mathrm{SiO}_{2}$ & ICDD- 96-901-2602 & 2.26 \\
3. & Cristobalite & $\mathrm{SiO}_{2}$ & ICDD- 96-900-9687 & 7.72 \\
4. & Alunite & $\mathrm{Al}_{3} \mathrm{H}_{12} \mathrm{~K}_{0.875} \mathrm{O}_{14.125} \mathrm{~S}_{2}$ & ICDD- 96-901-2351 & 2.91 \\
\hline
\end{tabular}

Referring to Table 2, it can be concluded that Anorthite compounds, $\mathrm{Al}_{2} \mathrm{CaO}_{8} \mathrm{Si}_{2}$ contain the mass fraction of $87.11 \% \mathrm{wt}$, Quartz compounds $\mathrm{SiO}_{2}$ contain mass fraction of $2.26 \% \mathrm{wt}$, Cristobalite compounds, $\mathrm{SiO}_{2}$ contain $7.72 \%$ wt and Alunite compounds, $\mathrm{Al}_{3} \mathrm{H}_{12} \mathrm{~K}_{0.875} \mathrm{O}_{14.125} \mathrm{~S}_{2}$ contain mass fraction of $2.91 \%$ wt.

\section{Conclusion}

Based on the analysis conducted on the volcanic rocks of Mount Sinabung, the conclusion is:

1. Volcanic rocks contain: Anorthite phase 87.11 (wt\%), the Triclinic crystals, lattice constants $\mathrm{a}=8.1742 \AA, \mathrm{b}=12.844 \AA, \mathrm{c}=14.204 \AA$; Quartz phase 2.26\%, Hexagonal crystals, lattice constants , $a=4.799 \AA, b=4.799 \AA, c=5.379 \AA$; Crystobalite phase 7.72 (wt\%), Tetragonal crystals, lattice constants $=4.970 \AA, \mathrm{b}=6.990 \AA, \mathrm{c}=6.998 \AA$; Alunite phase 2.91 (wt\%), Hexagonal crystals, lattice constant $\mathrm{a}=6.990 \AA \mathrm{A}, \mathrm{b}=6.990 \AA$ A, $\mathrm{c}=17.282$ $\AA$.

2. The volcanic rocks from Mount Sinabung contain Anorthite phase (87.11\%), and classified as Feldspar because its Triclinic crystal system can be used as the material of ceramics.

3. The microstructure of volcanic rocks has round shape with varied sizes. Some are oval with small part containing fine aggregate.

\section{Acknowledgement}

To Sahat M. Nababan and Ronald J. Naibaho for their assistance in analyzing the rock and volcanic dust sample of Mount Sinabung, Karo Regency by XRD, SEM-EDX.

\section{REFERENCES}

[1] N. F. Sinuhaji, "Analisis Logam Berat dan Unsur Hara Debu Vulkanik Gunung Sinabung Kabupaten Karo-Sumatera Utara," FMIPA, Universitas Sumatera Utara, Medan, 2010.

[2] A. Daniel, "Pengaruh Variasi Tekanan Terhadap Konstanta Kisi Debu Vulkanik Gunung Sinabung," FMIPA, Universitas Sumatera Utara, Medan, 2012.

[3] J. E. Wainwright and J. Starkey, "A Refinement of the Structure pf Anorthite," Zeitschriftfuer Kristallographie, Kristallgeometrie, Kristallphysik, Kristallchemie, vol. 133, pp. 75-84, 1971.

[4] R. J. Angel, "High-pressure Structure of Anorthite," American Mineralogist, vol. 73, pp. 1114-1119, 1988.

[5] L. Barbieri, F. Bondioli, I. Lancellotti, C. Leonelli, M. Montorsi, A. M. Ferrari and P. Miselli, "The Anorthite-diopside System: Structural and Devitrification Study. Part II: 
Crystallinity Analysis by The Rietveld-RIR Method," Journal of the American Ceramic Society, vol. 88, no. 11, pp. 3131-3136, 2005.

[6] R. J. Angel, M. A. Carpenter and L. W. FInger, "Structural Variation Associated with Compositional Variation and Order-disorder Behavior in Anorthite-rich Feldspars," American Mineralogist, vol. 75, no. 1-2, pp. 150-162, 1990.

[7] E. Bruno, G. Chiari and A. Facchinelli, "Anorthite quenched from 1530 CI Structure refinement," Acta Crystallographica Section B: Structural Crystallography and Crystal Chemistry, vol. 32, no. 12, pp. 3270-3280, 1976.

[8] R. M. Hazen, L. W. Finger, R. J. Hemley and H. K. Mao, "High-pressure Crystal Chemistry and Amorphization of Alpha-quartz Locality: Synthetic Sample: P=2.0 GPa," Solid State Communications, vol. 72, pp. 507-511, 1989.

[9] P. J. Heaney, C. T. Prewitt, G. V. Gibbs and editors, Silica: physical behavior, geochemistry, and materials applications, Walter de Gruyter GmbH \& Co KG, 2018.

[10] J. J. Pluth, J. V. Smith and J. Faber, "Crystal Structure of Low Cristobalite at 10, 293 and 473 K: Variation of Framework Geometry with Temperature Sample: T=293 K Locality: Synthetic," Journal of Applied Physics, vol. 57, pp. 1045-1049, 1985.

[11] H. D. Megaw, Crystal Structures; A Working Approach, Philadelphia: Saunders, 1973.

[12] G. V. Gibbs, "Molecules as Model for Bonding in SIlicates," American Mineralogist, vol. 67, no. 5-6, pp. 421-450, 1982.

[13] S. Lee and H. Xu, "Using Powder XRD and Pair Distribution Function to Determine Anisotropic Atomic Displacement Parameters of Orthorhombic Tridymite and Tetragonal Cristobalite," Acta Crystallographica Section B: Structural Science, Crystal Engineering and Materials, vol. 75, no. 2, pp. 160-167, 2019.

[14] H. Shelton, B. Tiange, E. Zurek, J. Smith and P. Dera, "Cristobalite XI: A Bridge Between Low and High Density Silica Polymorphs," in AGU Fall Meeting Abstracts, New Orleans, 2017.

[15] D. Anggreini , "Analisa SEM (Scanning Electron Microscopy) Pemantauan Proses Oksidasi Magnetite menjadi Hematite," in Seminar VII-Rekayasa dan Aplikasi Teknik Mesin di Industri, Bandung, 2009.

[16] S. Bijaksana, "Rock Magnetic Methods for Environmental Studies," in ASEANIP Regional Seminar on the Physics of Metals and Alloys, 1996.

[17] D. J. Dunlop, "Dunlop, D.J., Magnetism in Rock," Journal in Geophysical Research, vol. 100, no. B2, pp. 2161-2174, 1995.

[18] C. Klein, Manual of Mineralogy, New York, USA: Jhon Willey and Sons, 1993.

[19] M. Tucker, Techniques in Sedimentology, Oxford/London: Blackwell Scientific Publication, 1998.

[20] K. L. Verosub and A. P. Roberts, "Environmental Magnetism Past, Present and Future," Journal of Geophysical Research, vol. 100, no. B2, pp. 2175-2192, 1995. 